\title{
Association Between Formalin Fixation Time and Programmed Cell Death Ligand 1 Expression in Patients With Non-Small Cell Lung Cancer
}

\author{
HAYATO KAWACHI ${ }^{1}$, DAICHI FUJIMOTO ${ }^{1}$, DAISUKE YAMASHITA ${ }^{2}$, JUNYA FUKUOKA $^{3}$, YUKA KITAMURA ${ }^{3}$, \\ KAZUTAKA HOSOYA ${ }^{1}$, YUKI SATO ${ }^{1}$, KAZUMA NAGATA $^{1}$, ATSUSHI NAKAGAWA ${ }^{1}$, RYO TACHIKAWA $^{1}$, \\ NAOKI DATE ${ }^{4}$, ICHIRO SAKANOUE ${ }^{4}$, HIROSHI HAMAKAWA ${ }^{4}$, YUTAKA TAKAHASHI ${ }^{4}$ and KEISUKE TOMII ${ }^{1}$ \\ ${ }^{I}$ Department of Respiratory Medicine, Kobe City Medical Center General Hospital, Kobe, Japan; \\ ${ }^{2}$ Department of Pathology, Kobe City Medical Center General Hospital, Kobe, Japan; \\ ${ }^{3}$ Department of Pathology, Nagasaki University Graduate School of Biomedical Sciences, Nagasaki, Japan; \\ ${ }^{4}$ Department of Thoracic Surgery, Kobe City Medical Center General Hospital, Kobe, Japan
}

\begin{abstract}
Background/Aim: The expression of programmed cell death ligand 1 (PD-L1) determined by immunohistochemistry (IHC) may be associated with tissue formalin fixation time in non-small cell lung cancer (NSCLC) samples. We investigated the association between the PD-L1 expression and formalin fixation time, and clarified the optimal duration of fixation for accurate PD-L1 evaluation. Materials and Methods: We collected 55 tumor specimens from resected NSCLC patients. The samples were halved and immediately fixed in $10 \%$ buffered formalin for 12-24 h (normal fixation), or 96-120 h (prolonged fixation). Each specimen was stained using two assay systems (22C3 and SP263) for PD-L1. Results: The mean PD-L1 tumor proportion score was not significantly different between normal and prolonged fixation groups for either 22C3 or SP263 (normal fixation: $18.8 \%$; prolonged fixation: $16.3 \%, p=0.277$; normal fixation: 16.2\%; prolonged fixation: $17.6 \%, p=0.560$, respectively). Conclusion: Formalin fixation duration for up to 120 h does not affect PD-L1 IHC expression. PD-L1 tumor proportion score of tumor specimens can be evaluated by IHC even if these have been fixed in formalin outside the recommended duration in clinical practice.
\end{abstract}

Lung cancer is the leading cause of cancer-related deaths in the world (1). Non-small cell lung cancer (NSCLC) accounts for approximately $80 \%$ of all lung cancer cases and most

Correspondence to: Daichi Fujimoto, Department of Respiratory Medicine, Kobe City Medical Center General Hospital, 2-1-1 Minatojima-Minamimachi, Chuo-ku, Kobe 650-0047, Japan. Tel: +81 783024321, Fax: +81 783027537, e-mail: daichi@kcho.jp

Key Words: PD-1, PD-L1, immunohistochemistry, 22C3, SP263, fixation time, formalin fixation.
NSCLC cases are already advanced, unresectable, and metastatic at initial diagnosis (2). Recently, programmed death 1 (PD-1)/programmed death ligand 1 (PD-L1) axis inhibitors have demonstrated outstanding efficacy in patients with metastatic NSCLC, and have been established as novel standard treatment for NSCLC (3-8).

Tumor proportion score (TPS) for PD-L1, as determined by immunohistochemistry (IHC), is associated with improved treatment efficacy of PD-1 axis inhibitors, such as pembrolizumab $(9,10)$. Clinical trials have demonstrated the efficacy of pembrolizumab for NSCLC patients with PD-L1 TPS $\geq 50 \%$ or $\geq 1 \%(5,7,8)$. Since PD-L1 IHC determines the treatment strategy for NSCLC patients $(5,7-10)$, an accurate evaluation of PD-L1 expression by IHC is essential.

The evaluation of IHC expression can be affected by technical issues, including formalin fixation time. According to the guidelines established by the American Society of Clinical Oncology (ASCO) and the College of American Pathologists (CAP) for HER2 testing, specimens should be fixed in $10 \%$ neutral buffered formalin for 6-72 $\mathrm{h}$ (11). According to the ATLAS of PD-L1 IHC testing in lung cancer, published by the International Association for the Study of Lung Cancer (IASLC), a formalin fixation time of 6-48 $\mathrm{h}$ is recommended for PD-L1 IHC evaluation using the $22 \mathrm{C} 3$ assay (12). During PD-L1 evaluation with the SP263 assay, a reasonable formalin fixation time is considered to be 6-72 h (13). Although upper limits for the formalin fixation period have been imposed, the data on which these limits are based, are poorly documented. Therefore, it is important to experimentally verify the appropriate formalin fixation time for PD-L1 evaluation by IHC. In the present study, we investigated the association between formalin fixation time and PD-L1 expression in NSCLC patients, and clarified the optimal duration of fixation for accurate PD-L1 evaluation by IHC. 


\section{Materials and Methods}

Patients and sample processing. We collected a total of 55 NSCLC samples from resected lungs at Kobe City Medical Center General Hospital from February 2017 to December 2017. We excluded specimens diagnosed with adenocarcinoma in situ and minimally invasive adenocarcinoma, because sufficient tumor cells were needed for PD-L1 interpretation. The tumor samples of the resected lung specimens were divided into two parts and both were immediately placed in $10 \%$ buffered formalin. One portion of each tumor sample was fixed for 12-24 hours to ensure adequate fixation (normal fixation), which is the duration recommended by established guidelines $(12,13)$. The other portion was fixed for 96120 hours (prolonged fixation) (Figure 1). Following fixation, each tumor block was immediately processed for paraffin embedding. The PD-L1 in the resulting paraffin-embedded (FFPE) tumor blocks was then assessed using IHC to establish their TPS.

Patients who reported never having smoked were defined as nonsmokers, those who had smoked within 1 year of NSCLC diagnosis were categorized as current smokers, and the remaining patients were considered former smokers. All patients were classified on the basis of clinical stage according to the 7th edition TNM classification (14). All tumor specimens included in the pathological analysis were obtained with informed consent. The study was approved by the Ethics Committee of Kobe City Medical Center General Hospital (Hyogo, Japan). The research was conducted in accordance with the Declaration of Helsinki (15).

Evaluation of tissue IHC. Two assay systems (22C3 and SP263) were used to evaluate the expression of PD-L1 by IHC in NSCLC specimens. Tissue sections ( $4 \mu \mathrm{m}$ thick) were cut serially from FFPE tumor blocks and were then routinely deparaffinized and rehydrated. For the $22 \mathrm{C} 3$ assay, sections were stained with PD-L1 22C3 mouse monoclonal primary antibodies using the EnVision FLEX visualization system on a Dako Autostainer Link 48 system (Agilent Technologies, Santa Clara, CA) $(16,17)$. For the SP263 assay, sections were stained with rabbit monoclonal primary antibodies and a matched rabbit immunoglobulin G-negative control with an OptiView DAB IHC Detection Kit on a BenchMark XT automated staining platform (Ventana Medical

Systems, Tucson, AZ) (13).

Tumor PD-L1 scores of samples were evaluated by two independent pathologists according to the respective scoring algorithms for these assays. Each slide was randomized and anonymized, and PD-L1 TCs were considered positive when the cell membrane was partially or completely stained, regardless of the staining intensity. Hematoxylin and eosin (H \& E) staining was used to orient the IHC slides. The TPS of PD-L1 in TCs was expressed as the percentage of PD-L1-positive TCs in the overall tumor section, and was estimated in increments of 5\%, except in the case of $1 \%$ positivity. In the case of a disagreement, the slides were reexamined until consensus was reached. We set $1 \%, 25 \%$, and $50 \%$ as the cut-off values, according to the values used in previous prospective clinical trials of PD-1 axis inhibitors.

Statistical analysis. Concordance between normal fixation and prolonged fixation specimens was evaluated using the overall percentage of agreement (OPA) related to the $1 \%, 25 \%$, and $50 \%$ thresholds. A paired $t$-test was used to compare the TPS between specimens with normal fixation and prolonged fixation. A $p$-value of $<0.05$ was considered to indicate statistical significance. Statistical analyses were performed using JMP 11 software (SAS Institute, Cary, NC, USA).

\section{Results}

Patient characteristics. A total of 55 NSCLC patient specimens were collected for the present study, one of which did not contain enough tumor cells. Patient characteristics are summarized in Table I. The median patient age was 70.9 years, and most patients were men $(65 \%)$, had a smoking history $(67 \%)$, adenocarcinoma $(67 \%)$, and stage I NSCLC (74\%).

PD-L1 IHC evaluation by $22 C 3$ assay. We compared the TPS of PD-L1 according to the 22C 3 assay between the normal and prolonged fixation groups. The mean PD-L1 TPS was not significantly different between normal and prolonged fixation groups (normal fixation: $18.8 \%$; prolonged fixation: $16.3 \%, p=0.277$ ) (Figure $2 \mathrm{~A}$ ). We also assessed the TPS between normal and prolonged fixation groups using the $22 \mathrm{C} 3$ assay (Table II). The OPAs at the PDL1 expression cut-offs of $1 \%, 25 \%$, and $50 \%$ were $85 \%$, $94 \%$, and $91 \%$, respectively. Fourteen samples exhibited discordant category features between the normal and prolonged fixation groups: six belonged to a higher category in the normal fixation group compared to the prolonged one, while eight belonged to a lower category. Of these 14 samples, eight were negative (TPS <1\%) in one fixation group, but not in both and exhibited TPS values between $1 \%$ and $10 \%$ in the positive group. One was discordant because its TPS was $1-24 \%$ in one fixation group, but $25-49 \%$ in the other. Five samples were strongly positive (TPS $\geq 50 \%$ ) in one fixation group, but not in the other, and the TPS values of these five specimens, according to the normal and prolonged fixation group, were $80 \%$ and $20 \%, 75 \%$ and $30 \%, 60 \%$ and $25 \%, 30 \%$ and $70 \%$, and $20 \%$ and $65 \%$, respectively.

PD-L1 IHC evaluation by SP263 assay. We compared the TPS of PD-L1 using the SP 263 assay between FFPE samples fixed for normal and prolonged periods. The mean PD-L1 TPS was not significantly different between normal and prolonged fixation groups (normal fixation: 16.2\%; prolonged fixation: $17.6 \%, p=0.560$ ) (Figure 2B). We also assessed the TPS between normal fixation and prolonged fixation groups using the SP263 assay (Table III). The OPAs at the PD-L1 expression cut-offs of $1 \%, 25 \%$, and $50 \%$ were $80 \%, 94 \%$, and $93 \%$, respectively. Sixteen samples exhibited discordant category features between the normal and prolonged fixation groups. Of these 16 samples, three belonged to a higher category in the normal fixation group compared to the prolonged one, while 13 belonged to a lower category. In 


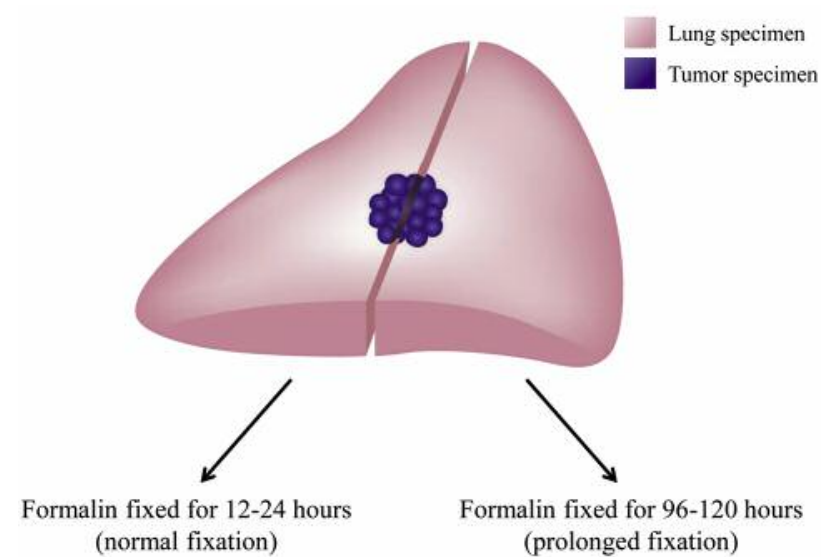

Figure 1. Schematic of specimen fixation procedure.

addition, 11 of these were negative (TPS $<1 \%$ ) in one group, but not in the other. Of these 11 samples, all exhibited TPS values between $1 \%$ and $5 \%$ in the positive group. One sample was discordant because it had a TPS of 1-24\% in one fixation group but $25-49 \%$ in the other. Four were strongly positive (TPS $\geq 50 \%$ ) in one group but not in the other and in these, the TPS values, according to the normal and prolonged fixation group, were $95 \%$ and $25 \%, 65 \%$ and $30 \%, 20 \%$ and $85 \%$, and $10 \%$ and $80 \%$, respectively.

PD-L1 IHC evaluation of patients with TPS $\geq 1 \%$ by $22 C 3$ assay. We also analyzed 27 tumor samples with a TPS $\geq 1 \%$, according to the $22 \mathrm{C} 3$ assay in the sample that had undergone normal fixation. The mean PD-L1 TPS obtained was not significantly different between normal and prolonged fixation groups (normal fixation: 32.6\%; prolonged fixation: $32.1 \%, p=0.231$ ) (Figure 2C). The OPAs at the PD-L1 expression cut-offs of $1 \%, 25 \%$, and $50 \%$ were $92 \%, 89 \%$, and $81 \%$, respectively (Table IV). In these samples, eight exhibited discordant results between normal and prolonged fixation groups, and of these eight samples, six belonged to a higher category in the normal fixation group compared to the prolonged one, and two belonged to a lower category.

PD-L1 IHC evaluation of patients with TPS $\geq 1 \%$ by SP263 assay. We also analyzed 28 tumor samples with TPS $\geq 1 \%$, according to the SP263 assay in the sample that had undergone normal fixation. The mean PD-L1 TPS according to the SP263 assay was not significantly different between normal and prolonged fixation groups (normal fixation: $31.3 \%$; prolonged fixation: $33.4 \%, p=0.659$ ) (Figure 2D). The OPAs at the PD-L1 expression cut-offs of $1 \%, 25 \%$, and $50 \%$ were $96 \%, 89 \%$, and $86 \%$, respectively (Table V). In these samples, six were discordant between the normal and
Table I. Characteristics of 54 non-small cell lung cancer patients recruited to test the effect of formalin fixation duration on programmed cell death ligand 1 immunohistochemistry analysis.

\begin{tabular}{lc}
\hline Characteristics & $\mathrm{n}(\%)$ \\
& $(\mathrm{N}=54)$ \\
\hline Age (years) & \\
Mean (SD) & $70.9(10.3)$ \\
Gender & $35(65)$ \\
Male & $19(35)$ \\
Female & \\
Smoking status & $18(33)$ \\
Non-smoker & $36(67)$ \\
Current or former & \\
Histology & $36(67)$ \\
Adenocarcinoma & $13(24)$ \\
Squamous cell carcinoma & $5(9)$ \\
Others & \\
Stage & $40(74)$ \\
I & $9(17)$ \\
II & $4(7)$ \\
III & $1(2)$ \\
IV & \\
\hline
\end{tabular}

SD: Standard deviation.

prolonged fixation groups. Of these, three belonged to a higher category in the normal fixation group compared to the prolonged one, and three belonged to a lower category.

\section{Discussion}

To the best of our knowledge, this is the first study to investigate the association between the PD-L1 TPS and formalin fixation time. Our results revealed that formalin fixation for up to 120 hours has no apparent effect on PDL1 IHC expression, according to both $22 \mathrm{C} 3$ and SP263 assay, and it is therefore possible to evaluate PD-L1 TPS in tumor samples that have been fixed for extended periods of time up to 120 hours.

In the present study, PD-L1-TPS was not significantly different between specimens with normal and prolonged fixation duration. We observed a similar result in tumor specimens with $\mathrm{TPS} \geq 1 \%$. For PD-L1 IHC testing in lung cancer, the previously recommended fixation protocol was with $10 \%$ buffered formalin for 6-48 hours $(12,13)$. However, the relevance of this recommendation was not supported by empirical evidence. Similarly, guidelines for HER2 IHC evaluation suggested a formalin fixation duration of 6-72 h, although previous reports had shown that fixation times between 3 and $168 \mathrm{~h}$ do not affect HER2 expression (11, 1820). Therefore, formalin fixation duration up to $120 \mathrm{~h}$ appears to have little to no impact on the expression of routine prognostic markers. Further investigations should be 
Table II. Comparison of programmed cell death ligand 1 tumor proportion score (TPS) at each cut-off level according to the $22 \mathrm{C} 3$ assay $(N=54)$.

\begin{tabular}{lrrrr}
\hline & \multicolumn{4}{c}{ Prolonged fixation } \\
\cline { 2 - 5 } TPS & $<1 \%$ & $1-24 \%$ & $25-49 \%$ & $\geq 50 \%$ \\
\hline Normal fixation & & & & \\
$\quad<1 \%$ & 21 & 6 & 0 & 0 \\
$1-24 \%$ & 2 & 10 & 0 & 1 \\
$25-49 \%$ & 0 & 1 & 1 & 1 \\
$\geq 50 \%$ & 0 & 1 & 2 & 8 \\
\hline
\end{tabular}

Concordant pairs: $0.74(40 / 54)$

Higher with normal fixation: $0.11(6 / 54)$

Higher with prolonged fixation: $0.15(8 / 54)$

Agreement (1\%, 25\%, 50\%): 85\%, 94\%, $91 \%$

Table III. Comparison of programmed cell death ligand 1 tumor proportion score (TPS) at each cut-off level according to the SP263 assay $(N=54)$.

\begin{tabular}{lrrrl}
\hline & \multicolumn{4}{c}{ Prolonged fixation } \\
\cline { 2 - 5 } TPS & $<1 \%$ & $1-24 \%$ & $25-49 \%$ & $\geq 50 \%$ \\
\hline Normal fixation & & & & \\
$\quad<1 \%$ & 16 & 10 & 0 & 0 \\
$1-24 \%$ & 1 & 13 & 1 & 2 \\
$25-49 \%$ & 0 & 0 & 2 & 0 \\
$\geq 50 \%$ & 0 & 0 & 2 & 7 \\
\hline
\end{tabular}

Concordant pairs: $0.70(38 / 54)$

Higher with normal fixation: $0.05(3 / 54)$

Higher with prolonged fixation: $0.24(13 / 54)$

Agreement (1\%, 25\%, 50\%): $80 \%, 94 \%, 93 \%$

Table IV. Comparison of programmed cell death ligand 1 tumor proportion score (TPS) at each cut-off for patients with a TPS $\geq 1 \%$ according to the $22 \mathrm{C} 3$ assay $(N=27)$.

\begin{tabular}{lcccc}
\hline & \multicolumn{4}{c}{ Prolonged fixation } \\
\cline { 2 - 5 } TPS & $<1 \%$ & $1-24 \%$ & $25-49 \%$ & $\geq 50 \%$ \\
\hline Normal fixation & & & & \\
$<1 \%$ & 0 & 0 & 0 & 0 \\
$1-24 \%$ & 2 & 10 & 0 & 1 \\
$25-49 \%$ & 0 & 1 & 1 & 1 \\
$\geq 50 \%$ & 0 & 1 & 2 & 8 \\
\hline
\end{tabular}

Concordant pairs: $0.70(19 / 27)$

Normal fixation higher: $0.22(6 / 27)$

Prolonged fixation higher: $0.07(2 / 27)$

Agreement (1\%, 25\%, 50\%): 92\%, 89\%, $81 \%$
Table V. Comparison of programmed cell death ligand 1 tumor proportion score (TPS) at each cut-off in patients with a TPS $\geq 1 \%$ according to SP263 assay $(N=28)$.

\begin{tabular}{lcccc}
\hline & \multicolumn{4}{c}{ Prolonged fixation } \\
\cline { 2 - 5 } TPS & $<1 \%$ & $1-24 \%$ & $25-49 \%$ & $\geq 50 \%$ \\
\hline Normal fixation & & & & \\
$\quad<1 \%$ & 0 & 0 & 0 & 0 \\
$1-24 \%$ & 1 & 13 & 1 & 2 \\
$25-49 \%$ & 0 & 0 & 2 & 0 \\
$\geq 50 \%$ & 0 & 0 & 2 & 7 \\
\hline
\end{tabular}

Concordant pairs: $0.79(22 / 28)$

Normal fixation higher: $0.11(3 / 28)$

Prolonged fixation higher: $0.11(3 / 28)$

Agreement (1\%, 25\%, 50\%): 96\%, 89\%, 86\%

conducted to determine the boundaries of the permissible formalin fixation time for PD-L1 IHC evaluation.

The present study was conducted using two major PD-L1 IHC assay systems, 22C3 and SP263. Currently, PD-L1 IHC $22 \mathrm{C} 3$ pharm, using the Dako autostainer, is the only assay that has been approved as a companion diagnostic for pembrolizumab use by the FDA (21). However, the Dako autostainer is not a common laboratory instrument as compared to the Ventana BenchMark platform, which is widely used (22). Therefore, in clinical practice, the utility of the Ventana platforms needs to be demonstrated. While the PD-L1 IHC assays of SP142 and SP263 require the use of Ventana platform, SP142 produced conflicting results, while 28-8, 22C3, and SP263 assays have produced concurring results (23-25). For these reasons, the Conformité Européene has allowed the SP263 assay to be used for PDL1 IHC assessment to facilitate treatment decisions for PD1 axis inhibitors (26). We, therefore, chose to assess the effects of fixation time for both the 22C3 and SP263 assays.

In clinical practice, lung biopsy tests or thoracic surgery are often performed on weekdays, while the laboratory that performs PD-L1 IHC evaluation is closed on weekends and holidays. If there is a long weekend, specimens received on Friday will be fixed for a minimum of $72 \mathrm{~h}$, which is beyond the recommended duration of fixation. The present study demonstrated that formalin fixation for up to $120 \mathrm{~h}$ has no significant effect on PD-L1 IHC analysis, and therefore, tissue specimens that have been fixed for longer than the recommended duration may be reliable for clinical evaluation of TPS.

In the present study, about $20 \%$ of NSCLC tumor samples had $\geq 50 \%$ PD-L1 expression, which is lower than advanced NSCLC tumor samples in several clinical trials (23-30\%) (7, $27,28)$. However, our study was conducted in patients with 
A

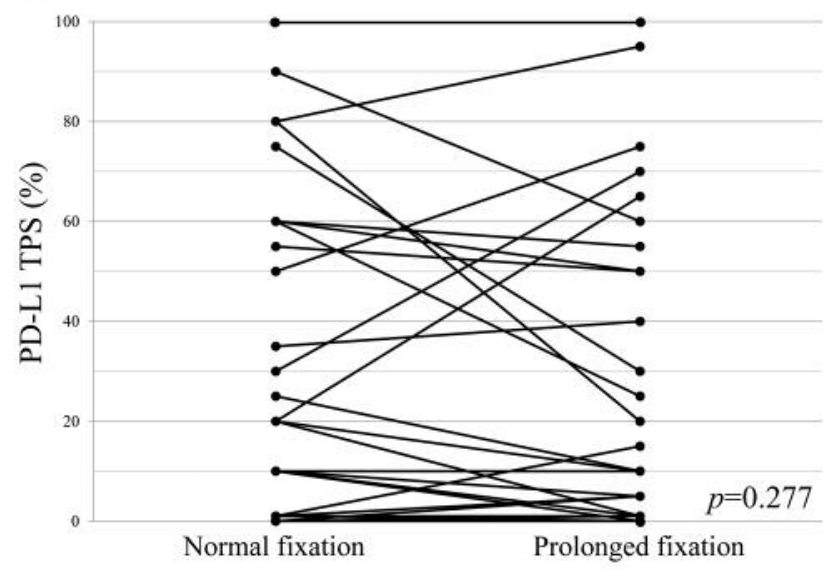

B

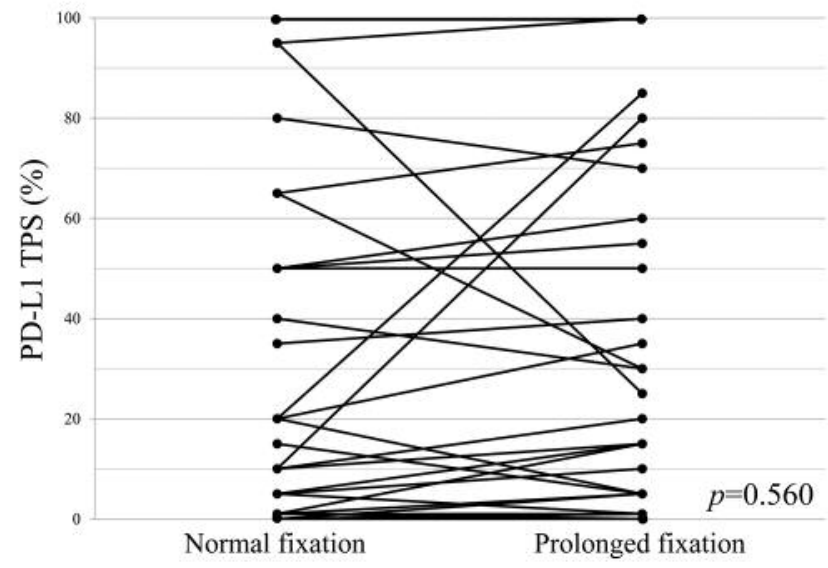

C

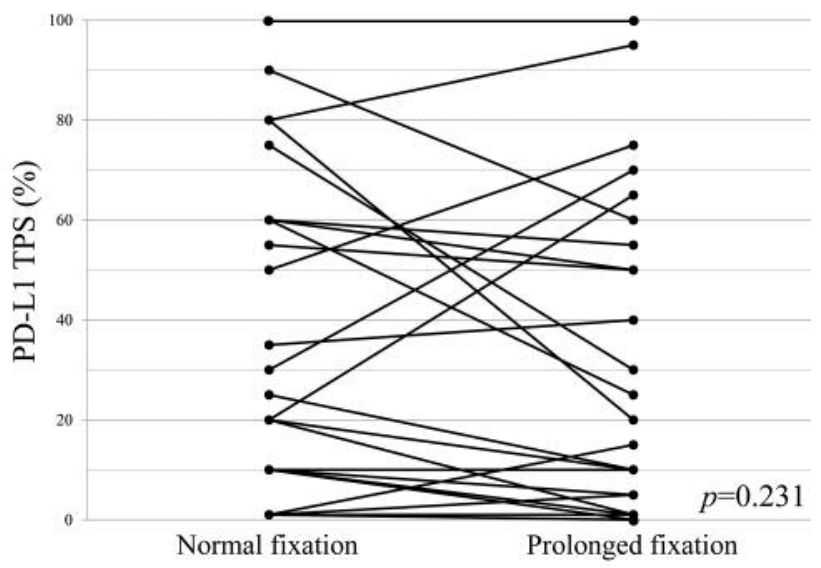

D

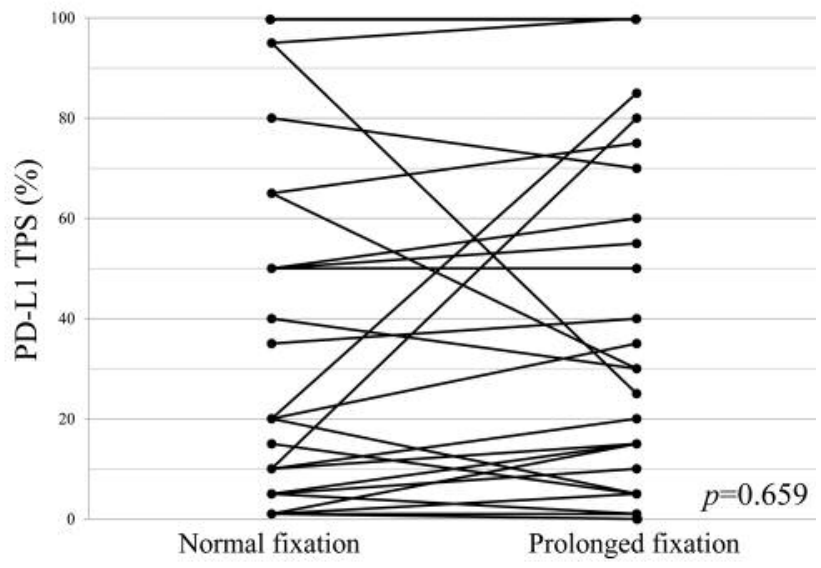

Figure 2. Comparison of programmed death ligand (PD-L1) tumor proportion score (TPS) values between normal fixation and prolonged fixation in (A) all tumor specimens according to $22 C 3$ assay, $(B)$ all tumor specimens in the SP263 assay (C), tumor specimens with TPS $\geq 1 \%$ according to the $22 C 3$ assay, and (D) tumor specimens with TPS $\geq 1 \%$ according to the SP263 assay.

an early-stage NSCLC, and in previous studies, 7-26\% of the surgically resected NSCLC specimens had $\geq 50 \%$ PD-L1 expression by $22 \mathrm{C} 3$ assays (29-31). Therefore, the proportion of samples with $\geq 50 \%$ PD-L1 expression in our cohort is representative of the clinical setting.

Although we found no significant differences in PD-L1 between different fixation treatment groups, our study had several limitations. First, this study had a single-center design with Japanese patients. Second, in advanced NSCLC patients, small biopsy samples are often used for PD-L1 assessment in clinical practice, however, in the present study, we analyzed only surgical specimens with an adequate number of tumor cells. Thus, a larger study cohort with small biopsy samples could validate our findings and establish optimal specimen processing methods for PD-L1 assessment.
In conclusion, we found that formalin fixation duration up to $120 \mathrm{~h}$ does not affect PD-L1 IHC expression in NSCLC specimens according to either 22C3 or SP263 assay. We therefore propose that PD-L1 IHC-based TPS can be established in clinical practice using tumor samples that have been formalin fixed for longer than the recommended duration.

\section{Conflicts of Interest}

Dr. Kawachi has received lecture fees from Ono Pharmaceutical Co., Ltd., Chugai Pharmaceutical, Merck Sharp and Dohme, and Taiho Pharmaceutical. Dr. Fujimoto has received lecture fees from Ono Pharmaceutical Co., Ltd., Bristol-Myers Squibb K.K., Chugai Pharmaceutical, AstraZeneca, Merck Sharp and Dohme, and Taiho 
Pharmaceutical. Dr. Fukuoka has received lecture fees from Merck Sharp and Dohme. Dr. Kitamura is the CEO of Pathology Institute Corporation and its stockholder. Dr. Hosoya has received lecture fees from Chugai Pharmaceutical, Merck Sharp and Dohme, and Taiho Pharmaceutical. Dr. Sato has received lecture fees from Ono Pharmaceutical Co., Ltd. Dr. Tomii has received lecture fees from Ono Pharmaceutical Co., Ltd., Bristol-Myers Squibb K.K., Chugai Pharmaceutical, AstraZeneca, Merck Sharp and Dohme, and Taiho Pharmaceutical. The remaining authors have declared that they have no conflicts of interest.

\section{Authors' Contributions}

DF designed the study. HK and DF wrote the initial draft of the manuscript, contributed to analysis and interpretation of data and assisted in the preparation of the manuscript. All other authors have contributed to data collection and interpretation, and have critically reviewed the manuscript. All authors approved the final version of the manuscript, and agreed to be accountable for all aspects of the work in ensuring that questions related to the accuracy or integrity of any part of the work were appropriately investigated and resolved.

\section{Acknowledgements}

This study was supported by internal funding and the Ethics Committee of Kobe City Medical Center General Hospital. The authors would like to thank Keiichiro Uehara, Yukihiro Imai, Kaori Shimoda and Yuki Imaoka for their contributions to the pathological analysis, and Hideshi Imoto, Keiko Sakuragawa, and Ayako Okamoto for administrative assistance.

\section{References}

1 Siegel RL, Miller KD and Jemal A: Cancer statistics, 2017. CA Cancer J Clin 67(1): 7-30, 2017. PMID: 28055103. DOI: $10.3322 /$ caac. 21387

2 Molina JR, Yang P, Cassivi SD, Schild SE and Adjei AA: Nonsmall cell lung cancer: Epidemiology, risk factors, treatment, and survivorship. Mayo Clin Proc 83(5): 584-594, 2008. PMID: 18452692. DOI: $10.4065 / 83.5 .584$

3 Brahmer J, Reckamp KL, Baas P, Crino L, Eberhardt WE, Poddubskaya E, Antonia S, Pluzanski A, Vokes EE, Holgado E, Waterhouse D, Ready N, Gainor J, Aren Frontera O, Havel L, Steins M, Garassino MC, Aerts JG, Domine M, Paz-Ares L, Reck M, Baudelet C, Harbison CT, Lestini B and Spigel DR: Nivolumab versus docetaxel in advanced squamous-cell nonsmall-cell lung cancer. N Engl J Med 373(2): 123-135, 2015. PMID: 26028407. DOI: 10.1056/NEJMoa1504627

4 Borghaei H, Paz-Ares L, Horn L, Spigel DR, Steins M, Ready NE, Chow LQ, Vokes EE, Felip E, Holgado E, Barlesi F, Kohlhaufl M, Arrieta O, Burgio MA, Fayette J, Lena H, Poddubskaya E, Gerber DE, Gettinger SN, Rudin CM, Rizvi N, Crino L, Blumenschein GR Jr., Antonia SJ, Dorange C, Harbison CT, Graf Finckenstein F and Brahmer JR: Nivolumab versus docetaxel in advanced nonsquamous non-small-cell lung cancer. N Engl J Med 373(17): 1627-1639, 2015. PMID: 26412456. DOI: $10.1056 /$ NEJMoa1507643

5 Reck M, Rodriguez-Abreu D, Robinson AG, Hui R, Csoszi T, Fulop A, Gottfried M, Peled N, Tafreshi A, Cuffe S, O'Brien M,
Rao S, Hotta K, Leiby MA, Lubiniecki GM, Shentu Y, Rangwala $\mathrm{R}$ and Brahmer JR: Pembrolizumab versus chemotherapy for PD-L1-positive non-small-cell lung cancer. N Engl J Med 375(19): 1823-1833, 2016. PMID: 27718847. DOI: 10.1056/NEJMoa1606774

6 Rittmeyer A, Barlesi F, Waterkamp D, Park K, Ciardiello F, von Pawel J, Gadgeel SM, Hida T, Kowalski DM, Dols MC, Cortinovis DL, Leach J, Polikoff J, Barrios C, Kabbinavar F, Frontera OA, De Marinis F, Turna H, Lee JS, Ballinger M, Kowanetz M, He P, Chen DS, Sandler A and Gandara DR: Atezolizumab versus docetaxel in patients with previously treated non-small-cell lung cancer (oak): A phase 3, open-label, multicentre randomised controlled trial. Lancet 389(10066): 255-265, 2017. PMID: 27979383. DOI: 10.1016/S0140-6736(16)32517-X

7 Herbst RS, Baas P, Kim DW, Felip E, Perez-Gracia JL, Han JY, Molina J, Kim JH, Arvis CD, Ahn MJ, Majem M, Fidler MJ, de Castro G Jr., Garrido M, Lubiniecki GM, Shentu Y, Im E, Dolled-Filhart $\mathrm{M}$ and Garon EB: Pembrolizumab versus docetaxel for previously treated, PD-L1-positive, advanced nonsmall-cell lung cancer (keynote-010): A randomised controlled trial. Lancet 387(10027): 1540-1550, 2016. PMID: 26712084. DOI: 10.1016/S0140-6736(15)01281-7

8 Lopes G, Wu Y-L, Kudaba I, Kowalski D, Cho BC, Castro G, Srimuninnimit V, Bondarenko I, Kubota K, Lubiniecki GM, Zhang J, Kush DA and Mok T: Pembrolizumab (pembro) versus platinum-based chemotherapy (chemo) as first-line therapy for advanced/metastatic nsclc with a PD-L1 tumor proportion score (tps) $\geq 1 \%$ : Open-label, phase 3 keynote-042 study. J Clin Oncol 36(18_suppl): LBA4-LBA4, 2018. DOI: 10.1200/JCO.2018. 36.18_suppl.LBA4

9 Abdel-Rahman O: Correlation between PD-11 expression and outcome of NSCLC patients treated with anti-PD-1/PD-L1 agents: A meta-analysis. Crit Rev Oncol Hematol 101: 75-85, 2016. PMID: 26969107. DOI: 10.1016/j.critrevonc.2016.03.007

10. Carbognin L, Pilotto S, Milella M, Vaccaro V, Brunelli M, Calio A, Cuppone F, Sperduti I, Giannarelli D, Chilosi M, Bronte V, Scarpa A, Bria E and Tortora G: Differential activity of nivolumab, pembrolizumab and mpdl3280a according to the tumor expression of programmed death-ligand-1 (PD-L1): Sensitivity analysis of trials in melanoma, lung and genitourinary cancers. PLoS One 10(6): e0130142, 2015. PMID: 26086854. DOI: 10.1371/journal.pone. 0130142

11. Wolff AC, Hammond ME, Hicks DG, Dowsett M, McShane LM, Allison KH, Allred DC, Bartlett JM, Bilous M, Fitzgibbons P, Hanna W, Jenkins RB, Mangu PB, Paik S, Perez EA, Press MF, Spears PA, Vance GH, Viale $G$ and Hayes DF: Recommendations for human epidermal growth factor receptor 2 testing in breast cancer: American society of clinical oncology/college of American pathologists clinical practice guideline update. J Clin Oncol 31(31): 3997-4013, 2013. PMID: 24101045. DOI: $10.1200 / J C O .2013 .50 .9984$

12. Tsao MS, Kerr KM, Dacic S, Yatabe Y and Hirsch FR: IASLC atlas of PD-L1 immunohistochemistry testing in lung cancer. IASLC, Aurora, CO, USA, 2017. Available from: https:// www.iaslc.org/sites/default/files/wysiwyg-assets/iaslc_pd11_atlas_mar2018_lo-res.pdf

13. Rebelatto MC, Midha A, Mistry A, Sabalos C, Schechter N, Li $\mathrm{X}$, Jin X, Steele KE, Robbins PB, Blake-Haskins JA and Walker $\mathrm{J}$ : Development of a programmed cell death ligand-1 immunohistochemical assay validated for analysis of non-small cell lung 
cancer and head and neck squamous cell carcinoma. Diagn Pathol 11(1): 95, 2016. PMID: 27717372. DOI: 10.1186/ s13000-0160545-8

14 Goldstraw P, Crowley J, Chansky K, Giroux DJ, Groome PA, Rami-Porta R, Postmus PE, Rusch V, Sobin L, International Association for the Study of Lung Cancer International Staging $\mathrm{C}$ and Participating I: The IASLC lung cancer staging project: Proposals for the revision of the tnm stage groupings in the forthcoming (seventh) edition of the tnm classification of malignant tumours. J Thorac Oncol 2(8): 706-714, 2007. PMID: 17762336. DOI: $10.1097 / J T O .0 b 013 \mathrm{e} 31812 \mathrm{f3c1a}$

15 World medical association declaration of helsinki: Ethical principles for medical research involving human subjects. JAMA 310(20): 2191-2194, 2013. PMID: 24141714. DOI: 10.1001/ jama.2013.281053

16 Phillips T, Simmons P, Inzunza HD, Cogswell J, Novotny J, Jr., Taylor C and Zhang X: Development of an automated PD-L1 immunohistochemistry (IHC) assay for non-small cell lung cancer. Appl Immunohistochem Mol Morphol 23(8): 541-549, 2015. PMID: 26317305. DOI: 10.1097/PAI.0000000000000256

17 Roach C, Zhang N, Corigliano E, Jansson M, Toland G, Ponto G, Dolled-Filhart M, Emancipator K, Stanforth D and Kulangara K: Development of a companion diagnostic PD-L1 immunohistochemistry assay for pembrolizumab therapy in non-small-cell lung cancer. Appl Immunohistochem Mol Morphol 24(6): 392-397, 2016. PMID: 27333219. DOI: 10.1097/PAI.0000 000000000408

18 Tong LC, Nelson N, Tsourigiannis J and Mulligan AM: The effect of prolonged fixation on the immunohistochemical evaluation of estrogen receptor, progesterone receptor, and her2 expression in invasive breast cancer: A prospective study. Am J Surg Pathol 35(4): 545-552, 2011. PMID: 21358301. DOI: 10.1097/PAS.0b013e31820e6237

19 Moatamed NA, Nanjangud G, Pucci R, Lowe A, Shintaku IP, Shapourifar-Tehrani S, Rao N, Lu DY and Apple SK: Effect of ischemic time, fixation time, and fixative type on her $2 /$ neu immunohistochemical and fluorescence in situ hybridization results in breast cancer. Am J Clin Pathol 136(5): 754-761, 2011. PMID: 22031314. DOI: 10.1309/AJCP99WZGBPKCXOQ

20 Ibarra JA and Rogers LW: Fixation time does not affect expression of her2/neu: A pilot study. Am J Clin Pathol 134(4): 594-596, 2010. PMID: 20855640. DOI: 10.1309/AJCPAIJ PSN4A9MJI

21 Fujimoto D, Yamashita D, Fukuoka J, Kitamura Y, Hosoya K, Kawachi H, Sato Y, Nagata K, Nakagawa A, Tachikawa R, Date N, Sakanoue I, Hamakawa H, Takahashi Y and Tomii K: Comparison of PD-L1 assays in non-small cell lung cancer: 22c3 pharmdx and sp263. Anticancer Res 38(12): 6891-6895, 2018. PMID: 30504406. DOI: 10.21873/anticanres.13065

22 Neuman T, London M, Kania-Almog J, Litvin A, Zohar Y, Fridel L, Sandbank J, Barshak I and Vainer GW: A harmonization study for the use of 22c3 PD-L1 immunohistochemical staining on Ventana's platform. J Thorac Oncol 11(11): 1863-1868, 2016. PMID: 27664534. DOI: 10.1016/j.jtho.2016.08.146

23 Hirsch FR, McElhinny A, Stanforth D, Ranger-Moore J, Jansson M, Kulangara K, Richardson W, Towne P, Hanks D, Vennapusa B, Mistry A, Kalamegham R, Averbuch S, Novotny J, Rubin E, Emancipator K, McCaffery I, Williams JA, Walker J, Longshore J, Tsao MS and Kerr KM: PD-L1 immunohistochemistry assays for lung cancer: Results from phase 1 of the blueprint PD-L1 IHC assay comparison project. J Thorac Oncol 12(2): 208-222, 2017. PMID: 27913228. DOI: 10.1016/j.jtho.2016.11.2228
24 Fujimoto D, Sato Y, Uehara K, Ishida K, Fukuoka J, Morimoto T, Kawachi H, Mori R, Ito M, Teraoka S, Nagata K, Nakagawa A, Otsuka K, Imai Y and Tomii K: Predictive performance of four programmed cell death ligand 1 assay systems on nivolumab response in previously treated patients with non-small cell lung cancer. J Thorac Oncol 13(3): 377-386, 2018. PMID: 29233789. DOI: $10.1016 /$ j.jtho.2017.11.123

25 Tsao MS, Kerr KM, Kockx M, Beasley MB, Borczuk AC, Botling J, Bubendorf L, Chirieac L, Chen G, Chou TY, Chung JH, Dacic S, Lantuejoul S, Mino-Kenudson M, Moreira AL, Nicholson AG, Noguchi M, Pelosi G, Poleri C, Russell PA, Sauter J, Thunnissen E, Wistuba I, Yu H, Wynes MW, Pintilie M, Yatabe Y and Hirsch FR: PD-L1 immunohistochemistry comparability study in real-life clinical samples: Results of blueprint phase 2 project. J Thorac Oncol 13(9): 1302-1311, 2018. PMID: 29800747. DOI: 10.1016/j.jtho.2018.05.013

26 Roche: Ventana PD-L1 (sp263) assay (ce ivd) (2019). Available from: https://diagnostics.roche.com/global/en/products/tests/ ventana-pd-11-_sp263-assay2.html. Last accessed on February 5 2019.

27 Garon EB, Rizvi NA, Hui R, Leighl N, Balmanoukian AS, Eder JP, Patnaik A, Aggarwal C, Gubens M, Horn L, Carcereny E, Ahn M-J, Felip E, Lee J-S, Hellmann MD, Hamid O, Goldman JW, Soria J-C, Dolled-Filhart M, Rutledge RZ, Zhang J, Lunceford JK, Rangwala R, Lubiniecki GM, Roach C, Emancipator K and Gandhi L: Pembrolizumab for the treatment of non-small-cell lung cancer. N Engl J Med 372(21): 20182028, 2015. PMID: 25891174. DOI: 10.1056/NEJMoa1501824

28 Reck M, Rodríguez-Abreu D, Robinson AG, Hui R, Csőszi T, Fülöp A, Gottfried M, Peled N, Tafreshi A, Cuffe S, O'Brien M, Rao S, Hotta K, Leiby MA, Lubiniecki GM, Shentu Y, Rangwala $\mathrm{R}$ and Brahmer JR: Pembrolizumab versus chemotherapy for PDL1-positive non-small-cell lung cancer. N Engl J Med 375(19): 1823-1833, 2016. PMID: 27718847. DOI: 10.1056/NEJMoa 1606774

29 Li C, Huang C, Mok TS, Zhuang W, Xu H, Miao Q, Fan X, Zhu W, Huang Y, Lin X, Jiang K, Hu D, Chen X, Huang P and Lin G: Comparison of 22c3 PD-L1 expression between surgically resected specimens and paired tissue microarrays in non-small cell lung cancer. J Thorac Oncol 12(10): 1536-1543, 2017. PMID: 28751245. DOI: 10.1016/j.jtho.2017.07.015

30 Heymann JJ, Bulman WA, Swinarski D, Pagan CA, Crapanzano JP, Haghighi M, Fazlollahi L, Stoopler MB, Sonett JR, Sacher AG, Shu CA, Rizvi NA and Saqi A: PD-L1 expression in non-small cell lung carcinoma: Comparison among cytology, small biopsy, and surgical resection specimens. Cancer Cytopathol 125(12): 896-907, 2017. PMID: 29024471. DOI: 10.1002/ cncy.21937

31 Cooper WA, Tran T, Vilain RE, Madore J, Selinger CI, Kohonen-Corish M, Yip P, Yu B, O’Toole SA, McCaughan BC, Yearley JH, Horvath LG, Kao S, Boyer M and Scolyer RA: PD$\mathrm{L} 1$ expression is a favorable prognostic factor in early stage nonsmall cell carcinoma. Lung Cancer 89(2): 181-188, 2015. PMID: 26024796. DOI: 10.1016/j.lungcan.2015.05.007

Received March 2, 2019

Revised April 11, 2019

Accepted April 12, 2019 